\title{
Personality factors in the elderly: The relationship between cognitive functioning and depressive symptoms
}

\author{
Valéria Gonzatti, Irani Iracema de Lima Argimon, Cristiane Silva Esteves, Tatiana Quarti Irigaray ${ }^{1}$ \\ Pontifícia Universidade Católica do Rio Grande do Sul, Porto Alegre-RS, Brasil \\ Camila Rosa de Oliveira \\ Faculdade Meridional, Passo Fundo-RS, Brasil \\ Carmen Moret-Tatay \\ Universidad Católica de Valencia San Vicente Mártir, Valencia, Espanha
}

\begin{abstract}
Personality factors have been highlighted as possible predictors for cognitive performance and depressive symptomatology in the elderly. The current study aims to investigate the relationship between the five principal personality factors, depressive symptomatology and cognitive performance of elderly during attention, memory and executive function tasks. Additionally, there was the attempt to investigate the predictor role played by depression symptoms and cognitive functioning in personality factors. The convenience sampling method was used and 72 elderly persons, aged between 60 and 85 years, were evaluated. They answered questions about sociodemographic conditions, personality factors (NEO-FFI-R), depressive symptomatology (GDS-15) and underwent an evaluation of their cognitive functions. Results showed a positive to moderate relationship between Neuroticism and depressive symptomatology, as well as a negative to moderate relationship between Openness to experience and depressive symptomatology. Depressive symptoms emerge as the strongest predictor correlated to the highest Neuroticism indices and the lowest of Extroversion, Openness to experience, and Conscientiousness. Non-perseverative errors on the WCST were strongly associated, with the higher scores on Neuroticism and lower in Extraversion in the sample. The investigation points towards the existence of a relationship among personality, depressive symptomatology, and cognitive functioning factors in the elderly, however, further studies are suggested.
\end{abstract}

Keywords: personality; aged; cognitive ability; depression.

RESUMO - Fatores de personalidade em idosos: relação com funcionamento cognitivo e sintomas depressivos Os fatores de personalidade têm sido apontados como possíveis preditores do desempenho cognitivo e sintomatologia depressiva na velhice. O presente estudo teve como objetivo investigar a relação entre os cinco grandes fatores de personalidade, sintomatologia depressiva e o desempenho cognitivo em tarefas de atenção, memória e funções executivas. Foi utilizado o método amostra de conveniência; 72 idosos (60-85 anos), responderam questões sobre condições sociodemográficas, fatores de personalidade (NEOFFI-R), sintomatologia depressiva (GDS-15) e avaliação das funções cognitivas. Os resultados mostraram uma relação positiva e moderada entre o fator Neuroticismo e sintomatologia depressiva; relação negativa e moderada entre o fator Abertura à Experiência e sintomatologia depressiva; sintomas depressivos apareceram correlacionados a índices mais altos de Neuroticismo e mais baixos de Extroversão, Abertura à experiência e Conscienciosidade; erros não perseverativos, no Teste Wisconsin de Classificação de Cartas (WCST) associaram-se aos escores mais altos em Neuroticismo e mais baixos em Extroversão. A investigação aponta para relação entre fatores de personalidade, sintomatologia depressiva e funcionamento cognitivo em idosos, contudo, outros estudos são sugeridos. Palavras-chave: personalidade; idosos; aptidão cognitiva; depressão.

RESUMEN - Factores de personalidad en los ancianos: la relación entre el funcionamiento cognitivo y los síntomas depresivos Los factores de personalidad se han destacado como posibles predictores del funcionamiento cognitivo y de la sintomatología depresiva en los ancianos. El presente estudio tiene como objetivo investigar la relación entre los cinco principales factores de personalidad, la sintomatología depresiva y el funcionamiento cognitivo de los ancianos durante la atención, la memoria y las tareas de la función ejecutiva. Además, hubo el intento de investigar el papel predictor desempeñado por los síntomas de la depresión y el funcionamiento cognitivo en los factores de personalidad. Se utilizó el método de muestreo de conveniencia. Setenta y dos ancianos, de 60-85 años de edad, fueron evaluados. Ellos respondieron acerca de las condiciones sociodemográficas, los factores de personalidad (NEO-FFI-R), la sintomatología depresiva (GDS-15) y se sometieron a una evaluación de sus funciones cognitivas. Los resultados mostraron una relación positiva y moderada entre neuroticismo y la sintomatología depresiva, así como una relación negativa y moderada entre apertura a la experiencia y la sintomatología depresiva. Los síntomas depresivos emergen como el predictor más fuerte correlacionado con los más altos índices de neuroticismo y los más bajos de extraversión, apertura a la experiencia y responsabilidad. En comparación con los otros, los errores no persistentes en el Teste de Clasificación de Tarjetas de Winsconsin (WCST) se asociaron fuertemente con las puntuaciones más altas en neuroticismo y las más bajas en extraversión. El estudio apunta hacia la existencia de una relación entre los factores de personalidad, la sintomatología depresiva y el funcionamiento cognitivo en ancianos; sin embargo, se sugieren otros estudios. Palabras clave: personalidad; adultos mayores; aptitud cognitiva; depresión. 
Personality, among countless definitions, may be conceptualized as an individual's characteristics. Personality is unique and distinguishes an individual from others due to behavioral patterns, feelings, and thoughts (Roberts \& Mroczek, 2008; Trentini et al., 2009). Starting with the Big Five Factors (BFF), personality assessment includes Neuroticism, Extroversion, Openness to experience, Agreeableness, and Conscientiousness factors. Neuroticism refers to stress experiences expressed in anxiety, anger, depression and feelings related to distress. Extroversion is related to sociability and liveliness. Openness to experience is associated with creativity, aesthetic sensitivity, intellectual curiosity and necessity of variety. Agreeableness is linked to confidence, altruism and sympathetic experiences. Conscientiousness refers to deeds, i.e., achieving targets and values (Fuentes et al., 2010; Löckenhoff, Terracciano, Ferrucci, \& Costa, 2012).

According to some studies (Chapman et al., 2012; Fonseca, 2006; Kuzma, Sattler, Toro, Schonknecht, \& Schroder, 2011), personality factors help the adaptation to the aging process and are linked to elderly cognitive performance (Chapman et al., 2012; Fuentes et al., 2010; Kuzma et al., 2011). High Neuroticism indices are related to poor elderly performance during cognitive tasks (Kuzma et al., 2011). However, Openness to experience appears as an important factor for cognitive capacity maintenance during the aging process (Fonseca, 2006).

A study conducted by Chapman et al. (2012), who followed up with elderly for a period of seven years, showed that high Neuroticism scores and low Openness to experience lead to worse cognitive functioning. The elderly with higher Conscientiousness levels present better cognitive functioning when compared to those with low scores in a period of five years. According to the authors, among the dimensions of the five factors model, the Openness to experience factor seems to be one of the predictors of good cognitive functioning in the elderly.

High Neuroticism indices represent a risk factor to the development of mild cognitive decline (MCD) and dementia in the elderly (Chapman et al., 2012; Kuzma et al., 2011; Löckenhoff et al., 2012; Terracciano et al., 2014; Wilson et al., 2003). Neuroticism seems to be associated with risk behaviors to health such as metabolic syndrome, low immune responses, and early mortality. In a study by Kuzma et al. (2011), MDC elderly presented higher Neuroticism scores and lower Openness to experience scores in all the tests when compared with healthy controls. According to the authors, MDC elderly differ in their pre-morbid personality in comparison to healthy controls due to the presented risk behaviors, such as tobacco use.

Specifically regarding elderly performance in $\mathrm{cog}$ nitive tasks, Sutin et al. (2011) pinpoints that high Extroversion indices and low Neuroticism are associated with better performances of elderly during episodic memory tasks. Contrastingly, elderly with high Neuroticism indices scored lower verbal fluency levels when compared to the extroverted elderly. In their study, individuals with low Neuroticism, Extroversion and Open to experiences had better performance in verbal fluency, even after taking the effects of age, gender, and education under consideration. According to the authors, personality factors, i.e., the individual's way of thinking, feeling and behaving, seem to be linked to the capacity of retrieving specific words.

Booth, Schinka, Brown, Mortimer, and Borenstein (2006) verified that Openness to experience is significantly related to verbal memory indices and with general cognitive capacity. This is mostly likely due to the fact that personality factors promote behavior patterns throughout life; it leads individuals to get involved with learning and leisure activities. Thus, individuals with history of involvement with these activities might be more capable of keeping their cognitive functioning, even when age advances.

Still, there are studies that point towards the link among personality factors, depression and cognitive functioning in the elderly (Ayotte, Potter, Williams, Steffens, \& Bosworth, 2009; Irigaray \& Schneider, 2007; Koorevaar et al., 2013; Wilson et al., 2003). Personality helps to trigger depressive symptomatology in the elderly (Irigaray \& Schneider, 2007), so it is important to the diagnosis as well as the severity and the beginning of depression among the elderly (Koorevaar et al., 2013). As per Weiss et al. (2009), high levels of Neuroticism and low Conscientiousness are the risk factors for depression expression in the elderly.

According to Ayotte et al. (2009), depressed individuals present worse performance in cognitive tasks when compared to non-depressed ones, thus they show worse performance in executive function tasks (Beats, Sahakian, \& Levy, 1996; Boone et al., 1995) and slowness in processing speed (Nebes et al., 2000). In the study by Ayotte et al. (2009), which compared 75 depressed elders with 103 non-depressed ones to analyze their cognitive functioning and personality traits, it was verified that stronger Openness to experience is related to better performance in parts A and B of the Trail Making test among depressed elderly and also related to better performance in the Backward Digit Span in all participants. Additionally, they found that high Neuroticism levels were related to worse performance in the Backward Digit Span, although just among depressed elderly. Yet, depressed participants have presented worse performance in the digits and in verbal fluency. Within their study, the authors concluded that Openness to experience has changed the relationship between depression and neuropsychological functioning in the elderly.

Few studies have been investigating the link between cognition and personality factors in the elderly by means of the Big Five Factors model (Ayotte et al., 2009). Thus, the current study aims to investigate the 
relationship among the Big Five Factors of personality, depressive symptomatology and elderly cognitive performance regarding attention, memory, and executive functions tasks. Additionally, there was the attempt to investigate the predictor role played by the depression symptoms and the cognitive functioning in personality factors of the elderly.

\section{Method}

\section{Design}

It is a transversal observational study with a descriptive-analytical approach.

\section{Participants}

The target population in the current study refers to the elderly who participate in social companionship groups and the sample itself was comprised of 72 individuals, recruited by the non-probabilistic sampling method according to their participation in social companionship groups for the elderly in the city of Porto Alegre and in Porto Alegre's Metropolitan Region. Inclusion criteria were:

- be aged 60 years or more and

- $\quad$ agree to participate. Exclusion criteria were:

- presence of uncorrected auditory and visual problems that could interfere in the tasks;

- a score of under 26 points on the Mini Mental State Examination (MMSE) for seniors with high educational levels and less than 18 points for elderly people with low educational levels (Chaves \& Izquierdo, 1992);

- be illiterate;

- the presence of moderate to severe depressive symptoms, namely a high score of six points on the Geriatric Depression Scale (version consists of 15 items; Yesavage et al., 1983).

These criteria were evaluated during the implementation of MMSE in an individual interview.

Initially, 84 elders were evaluated, and one was excluded due to their MMSE score, and the other 11 were excluded due to the fact that they did not answer some of the other cognitive tests. Thus, 72 (60-85 years old; $M=69.26 ; S D=5.83$ ) elderly persons actually joined the current study.

\section{Instruments}

Sociodemographic data. The sociodemographic data sheets included the following variables: age, gender, marital status, level of schooling, economic classification criterion (ABEP, 2008), housing, current occupation, leisure activity, physical and mental condition, use of medication, tobacco and alcohol use (amount and frequency), exercise, and the participation in elderly companionship groups.
Evaluation on Personality factors. NEO Five Factors Inventory Revised - NEO-FFI-R (Costa \& McCrae, 2010) is the short version of the $S$ form of the NEO-PI-R (NEO Personality Inventory revised), and it offers a brief and understandable measurement of the five personality domains. It is composed of 60 affirmative questions which participants must answer using one of the five described alternatives that vary from "totally disagree" to "totally agree". The five domains, which are Neuroticism, Extroversion, Openness to experience, Agreeableness and Conscientiousness, are each represented by 12 items that measure the domain. This instrument suits people over the age of 18, but it does not have normative data for over-60 individuals within the Brazilian context (Costa \& McCrae, 2010). This instrument's Cronbach's alpha coefficient varied between .70 and .83 in different factors.

Evaluation on Cognitive Functioning. The Mental Condition Mini Examination (MMSE) (Chaves \& Izquierdo, 1992) is a screening test to detect cognitive impairment used in the current study in order to exclude elderly who had scores that suggested dementia. The MMSE is an assessment tool for cognitive functions. It consists of questions that assess orientation to time, orientation to place, three-word registration, attention and calculation, memory of three words, language, and visual constructive capacity. The score can range from zero to 30 points with a cutoff of 24 points.

The Rey Auditory-Verbal Learning Test (RAVLT) was used to assess learning, recall, and recognition processes of the episodic memory (Cotta et al., 2012). There are RAVLT normative data from Brazilian elderly (Salgado et al., 2011). This instrument's Cronbach's alpha coefficient in the study by Malloy-Diniz, Lasmar, Gazinelli, Fuentes, and Salgado (2007) was .85.

The Phonemic Verbal Fluency Test (FAS) was used to assess the phonemic verbal fluency, which is also a sensitive measurement of executive functions (Strauss, Sherman, \& Spreen, 2006). In a study by Machado et al. (2009), normative data for the elderly population (60-93) are presented. FAS presented a Cronbach's alpha of .83 (Tombaugh, Kozak, \& Rees, 1999).

The Semantic Verbal Fluency Test (Animals' category) is a measure of executive functions processing, mainly to check on the capacity of organizing thoughts and the strategies used to search for words (Strauss et al., 2006). Brucki, Malheiros, Okamoto, and Bertolucci (1997) presented normative data from elderly individuals.

Wisconsin Card Sorting Test (WCST): short version comprises 64 cards. It assesses the cognitive flexibility, abstract reasoning, inhibition, and the capacity to generate problemsolving strategies (Kongs, Thompson, Iverson, \& Heaton, 2000; Trentini, Argimon, Oliveira, \& Werlang, 2010).

Wechsler Adults Intelligence Scale - Third Edition (WAIS-III): The Digits subtest evaluates working 
memory, the extension of verbal concentrated attention, the retention of immediate memory, and reversibility capacity which is composed of a sequence of numbers directly and inversely stated. There are normative data from elderly (Figueiredo \& Nascimento, 2007; Wechsler, 2004).

The Trail Making Test (TMT) assesses attention, mental flexibility, visual processing speed, and praxis function (Lezak, Howieson, Loring, \& Tranel, 2012). There are several Brazilian studies that present TMT data from elderly (Hamdan \& Bueno, 2005; Mota, Banhato, Silva, \& Cupertino, 2008).

The Iowa Gambling Task (IGT) is a computer test that helps evaluate decision-making (Bechara, 2007; MalloyDiniz et al., 2008). There are studies with IGT for the elderly population (Nguyen et al., 2013; Schneider \& Parente, 2006; Wood, Busemeyer, Koling, Cox, \& Davis, 2005).

Tower of London (TOL) assesses planning capacity and cognitive flexibility (Krikorian, Bartok, \& Gay, 1994; Moreira, Malloy-Diniz, Fuentes, Correa, \& Lage, 2010). There are Brazilian studies that applied the Tower of London to the elderly (Moreira et al., 2010; Paula, Costa, Moraes, Nicolato, \& Malloy-Diniz, 2012). They used the computer version made available by the Neuropsychology Laboratory, which is coordinated by Dr. Daniel Fuentes and that is also linked to Centro de Apoio a Pesquisa do Instituto de Psiquiatria do HC-FMUSP (Research Support Center of the Psychiatric Institute of HC-FMUSP).

Depressive symptomatology. Geriatric Depression Scale (GDS-15), is a measure used to identify and quantify depression symptoms in elderly. The instrument's short version in Portuguese comprised of 15 items was used (Yesavage et al., 1983).

\section{Procedures}

Data collection. First, the current study was approved by the Research Ethics. After the approval, contact was made with elderly social companionship groups in Porto Alegre and in the Metropolitan Region. Participants were invited to join the study. The elderly who had accepted the invitation, filled out and signed the Informed Consent. Next, they answered the MMSE, and those who met the inclusion criteria participated in the study.

The evaluations of the participants were individually conducted in two meetings, as follows:

1. $1^{\text {st }}$ meeting: MMSE, sociodemographic data sheet, digits, TMT, RAVLT (Lists from A1 to A5, B1 to A6), WCST, and RAVLT (A7) with each test possessing a mean duration of two hours. The application of recognition memory instruments was carried out at the end this meeting;

2. $2^{\text {nd }}$ meeting: IGT, Verbal Fluency (FAS and animals), TOL, NEO-FFI-R, and GDS-15. Secrecy regarding identity was ensured to the participants in the study, participation was voluntary and those who needed referrals were sent to Serviço de Atendimento Psicológico e Pesquisa (SAPP).

Data analysis. Data description was completed by means of absolute $(n)$ and relative (\%) frequencies for the categorical variables, and by average and standard deviation for the continuous variables. The instruments were graded according to their respective manuals. The tests without manuals and/or normative data for the Brazilian population were analyzed by gross scores. The significance level used in the analysis was $5 \%$. The Pearson correlation was used in order to evaluate the relationship among personality factors, cognitive functioning and depression symptoms in the elderly, since the data have presented normal distribution according to the Kolmogorov-Smirnov test.

The relevant results from the correlation analysis were considered and the Multiple Linear Regression Analysis was implemented through the Stepwise model with multi-colinearity diagnosis as well as the self-correlation (dependency) analysis by Durbim Watson in order to investigate whether the personality factors could explain the cognitive functioning and the expression of depression symptoms.

\section{Results}

Table 1 shows the sociodemographic data from the sample. As can be seen, $76.4 \%$ were female. Regarding marital status, $54.2 \%$ did not have a companion. The majority

Table 1

Socio-demographic features of the sample $(n=72)$

\begin{tabular}{lcc}
\hline Variables' profile & $n$ & $\%$ \\
\hline Gender & 17 & 23.6 \\
$\quad$ Male & 55 & 76.4 \\
$\quad$ Female & & \\
School level & 34 & 47.2 \\
$\quad$ Elementary and high school & 38 & 52.8 \\
$\quad$ College degree & & \\
Marital status & 33 & 45.8 \\
$\quad$ Married - with a companion & 39 & 54.2 \\
$\quad$ Without companion & & \\
Medication & 69 & 95.8 \\
Yes & 3 & 04.2 \\
No & & \\
Economic class & 19 & 26.4 \\
C and D & 53 & 73.6 \\
A and B & & \\
\hline
\end{tabular}


of the participants had a college degree (52.8\%), used some type of medication (use of medications continued: diabetes, hypertension, cholesterol) (95.8\%), and belonged to the $\mathrm{A}$ and $\mathrm{B}$ classes $(73.6 \%)$ according to the economic classification criterion (ABEP, 2012).

The evaluation by linearity degree through correlation (Table 2) showed a positive to moderate relationship between the Neuroticism factor and the total GDS score $(r=.507 ; p<.001)$. A negative to moderate relationship was found between the Openness to experience factor and the total GDS-15 score $(r=-.352 ; p<.001)$. It was possible to verify positive and weak relationships, but significant, between the Openness to experience factor and the total RAVLT score (A1 to a5) $(r=.284 ; p<.005)$. There were negative and weak correlations, but significant, between the Agreeableness factor and RAVLT (List A7) $(r=-.235 ; p<.05)$, the Vocabulary gross score $(r=-.239 ; p<.05)$, and the total score for Tower of London $(r=-.284 ; p<.005)$. Additionally, a significant and positive association was also found, although weak,

Table 2

Correlations between Personality factors, depression symptoms and Performance in cognitive tasks

\begin{tabular}{|c|c|c|c|c|c|}
\hline & Neuroticism & Extroversion & Openness & Agreeableness & Conscientiousness \\
\hline GDS-15 & $.507^{* *}$ & -.192 & $-.352^{* *}$ & -.115 & -.215 \\
\hline MMSE & .023 & -.058 & .128 & -.194 & -.203 \\
\hline Digits (OD) & -.094 & -.067 & .070 & -.190 & .015 \\
\hline Digits (OI) & -.034 & .010 & -.046 & -.178 & -.050 \\
\hline Trail (Time Part A) & .226 & -.181 & -.139 & -.103 & .054 \\
\hline Trail (Time Part B) & .122 & -.162 & -.151 & .032 & .048 \\
\hline Trail (Errors Part A) & .187 & -.151 & -.097 & .226 & .111 \\
\hline Trail (Errors Part B) & .162 & -.088 & -.060 & .093 & .021 \\
\hline RAVLT (A1 to A5) & .024 & -.053 & $.284^{*}$ & -.196 & -.039 \\
\hline RAVLT (List B1) & .097 & -.049 & .196 & -.187 & -.065 \\
\hline RAVLT (List A6) & .101 & .085 & .135 & -.184 & -.131 \\
\hline RAVLT (List A7) & .149 & -.027 & .066 & $-.235^{*}$ & -.180 \\
\hline RAVLT (recognition) & .071 & -.011 & -.005 & -.139 & $-.271^{*}$ \\
\hline WCST (conceptual answers) & .074 & -.081 & .032 & -.224 & -.196 \\
\hline WCST (Categories) & .136 & -.035 & .081 & -.120 & -.189 \\
\hline WCST (Attempts) & -.071 & .088 & .031 & .197 & .160 \\
\hline WCST (Fail on keeping the context) & -.048 & -.169 & -.079 & -.124 & -.114 \\
\hline WCST (Learning to learn) & -.014 & .004 & .107 & .020 & -.179 \\
\hline WCST (Errors) & -.066 & .092 & -.028 & .181 & .180 \\
\hline WCST (perseverative answers) & .103 & -.128 & -.051 & .041 & $.273^{*}$ \\
\hline WCST (perseverative mistakes) & .123 & -.128 & -.065 & .052 & $.253^{*}$ \\
\hline WCST (Non- perseverative mistakes) & -.215 & $.251^{*}$ & .036 & .161 & -.060 \\
\hline $\begin{array}{l}\text { WCST (percentage of } \\
\text { conceptual answers) }\end{array}$ & .074 & -.081 & .032 & -.224 & -.196 \\
\hline FAS & -.142 & .020 & .222 & -.230 & -.018 \\
\hline Animals & -.005 & .126 & .132 & -.033 & .017 \\
\hline IGT & -.001 & -.099 & .018 & -.062 & .018 \\
\hline Vocabulary & .034 & .010 & .080 & $-.239^{*}$ & -.132 \\
\hline Tower of London & -.079 & .109 & .072 & $-.284^{*}$ & -.196 \\
\hline
\end{tabular}

Note: ${ }^{*} p \leq .05 .{ }^{* *} p \leq .001$. GDS 15=Geriatric Depression Scale; RAVLT=Rey Auditory-Verbal Learning Test; WCST=Wisconsin Card Sorting Test; FAS=Phonemic Verbal Fluency Test; IGT=Iowa Gambling Task. 
between the Conscientiousness factor and the RAVLT (recognition) $(r=-.271 ; p<.05)$. Weak and positive, although significant, correlations were observed between the Conscientiousness factor and the WCST in the persistent answers $(r=.273 ; p<.05)$ and in the persistent mistakes $(r=.253 ; p<.05)$.

A linear regression analysis was done with the intention to verify whether depression symptoms and the cognitive performance were predictors of elderly personality factors. As shown in Table 3, depression symptoms, the score in the RAVLT (A7) and the non-persistent mistakes in WCST were Neuroticism predictors, $R^{2}=.340 ; F=13.216 ; p \leq .001$, thus explaining the $36.8 \%$ of variance in this factor. Depression symptoms and the non-persistent mistakes in WCST emerged as Extroversion predictors $\left(R^{2}=.84 ; F=4.254\right) ; p<.018$, thus explaining the $11 \%$ variance in this factor. Depression symptoms and the RAVLT (A1t-A5) were predictors linked to
Openness to experience in the elderly $\left(R^{2}=.140\right.$; $F=6.785) ; p<.002$ and explained the $16.4 \%$ variance in this factor. The total score in the Tower of London appears as the only predictor of the Agreeableness factor, $R^{2}=.067 ; F=6.138 ; p<.016$, thus explaining the $8.1 \%$ variance in this factor. The depression symptoms, RAVLT (recognition) and the persistent answers in the WCST were predictors associated to the Conscientiousness factor $R^{2}=.067 ; F=6.138$; $p<.016$, thus explaining the $17.6 \%$ variance in this factor. It was observed that the depression symptoms emerged as the most strongly predictor correlated, compared to the other relations, to the highest Neuroticism indices and to the lowest Extroversion, Openness to experience and Conscientiousness within the studied sample. The non-persistent mistakes in the WCST are strongly associated to the highest Neuroticism scores and to the lowest ones in extroversion within the studied sample.

Table 3

Multiple Linear Regression Analysis to predict the role of personality factors in the expression of depression symptoms and in elderly cognitive functioning

\begin{tabular}{|c|c|c|c|c|c|c|c|}
\hline \multirow{2}{*}{ Models } & \multicolumn{4}{|c|}{ Regression coefficient } & \multicolumn{3}{|c|}{ Parameters of the model } \\
\hline & $B$ & SE & $\beta$ & $p_{(b)}$ & $R^{2}$ & $F$ & $p$ \\
\hline \multicolumn{8}{|l|}{ Neuroticism } \\
\hline \multicolumn{8}{|l|}{ Step5 } \\
\hline GDS-15 & 1.191 & .207 & .565 & $<.001$ & \multirow{3}{*}{.340} & \multirow{3}{*}{13.216} & \multirow{3}{*}{$\leq .001$} \\
\hline RAVLT (A7) & .403 & .188 & .212 & .035 & & & \\
\hline WCST non-perseverative mistakes & -.088 & -.088 & -.234 & .019 & & & \\
\hline \multicolumn{8}{|l|}{ Extroversion } \\
\hline \multicolumn{8}{|l|}{ Step5 } \\
\hline GDS-15 & -.439 & .231 & -.217 & .061 & \multirow{2}{*}{.084} & \multirow{2}{*}{4.254} & \multirow{2}{*}{.018} \\
\hline WCST non-perseverative mistakes & .097 & .041 & .271 & .020 & & & \\
\hline \multicolumn{8}{|l|}{ Openness to experience } \\
\hline \multicolumn{8}{|l|}{ Step4 } \\
\hline GDS-15 & -.664 & .253 & -.299 & .011 & \multirow{2}{*}{.140} & \multirow{2}{*}{6.785} & \multirow{2}{*}{.002} \\
\hline RAVLT (A1-A5) & .132 & .072 & .207 & .073 & & & \\
\hline \multicolumn{8}{|l|}{ Agreeableness } \\
\hline \multicolumn{8}{|l|}{ Step14 } \\
\hline Tower of London & -.192 & .078 & -.284 & .016 & .067 & 6.138 & .016 \\
\hline \multicolumn{8}{|l|}{ Conscientiousness } \\
\hline \multicolumn{8}{|l|}{ Step9 } \\
\hline GDS-15 & -.464 & .215 & -.238 & .034 & & & \\
\hline RAVLT (recognition) & -.185 & .094 & -.224 & .052 & .140 & 4.852 & .004 \\
\hline WCST Perseverative answers & .055 & .026 & .236 & .041 & & & \\
\hline
\end{tabular}

Note: $B=$ estimated regression coefficient; $S E=$ standard error of the regression coefficient; $\beta=$ standardized regression coefficient; $R^{2}=R^{2}$ ajusted; $p_{(b)}=$ Levels of significance of the coefficients. 


\section{Discussion}

The current study main goal was to investigate the relationship among the big five personality factors, depression symptoms, and elderly cognitive performance in attention, memory, and executive function tasks. Additionally, there was the attempt to investigate the predictor role played by the depression symptoms and the cognitive performance in elderly personality factors.

In the current study, a positive to moderate relationship was verified between the Neuroticism factor and the total GDS-15 score. Such a result indicates that the higher the neuroticism indices are, the stronger the depressive symptomatology is in the elderly. It corroborates the findings of other studies (Ayotte et al., 2009; Koorevaar et al., 2013; Tsubota-Utsugi et al., 2014; Weiss et al., 2009). Neuroticism, besides being a risk factor to trigger depression, represents a risk for functional decline among the elderly in the future (Tsubota-Utsugi et al., 2014) and it is associated to Alzheimer's Disease (Terracciano et al., 2014). Some studies state the hypothesis that Neuroticism is related to reduced brain volume (Knutson, Momenan, Rawlings, Fong, \& Hommer, 2001) and to risk behaviors to health such as metabolic syndrome, early mortality (Löckenhoff et al., 2012), and inflammation (Sutin et al., 2010). Additionally, individuals with high Neuroticism levels tend to evaluate their health pessimistically and present unfavorable social comparisons (Löckenhoff et al., 2012).

Still regarding correlations, a negative to moderate relationship was verified between the Openness to experience factor and the total GDS-15 score. Thus, it is possible to verify that the lower the Openness to experience is, the higher the depressive symptomatology in the elderly. An explanation hypothesis for this result would be the fact that the presence of depression symptoms could lead to worse executive functioning, such as lower cognitive flexibility, which in turn would cause lower Openness to experience (Ayotte et al., 2009). Thus, depression symptoms would be linked to cognitive inflexibility, i.e., to lower Openness to experience.

The multiple linear regression analysis corroborated the positive role of depression symptoms as the strongest predictor factor associated, in regards to the others, with the highest Neuroticism indices and the lowest extroversion, Openness to experiences and Conscientiousness within the studied sample. Other studies (Ayotte et al., 2009; Koorevaar et al., 2013; Tsubota-Utsugi et al., 2014; Weiss et al., 2009) corroborate this finding and indicate that different combinations of the Big Five Factors of personality, along with the high Neuroticism indices, would be the risk factors for depression in the elderly. The study by Koorevaar et al. (2013) found a relationship between Neuroticism scores and Conscientiousness and Extroversion as risk factors for depression in elderly. According to Weiss et al. (2009), elderly with high
Neuroticism levels and low Conscientiousness present higher vulnerability to develop depression. In addition, Ayotte et al. (2009) verified that depressed elderly present high Neuroticism indices and low Openness to experience, Conscientiousness and Extroversion.

It was observed that the non-persistent mistakes in the WCST are strongly related to higher Neuroticism scores and to lower Extroversion scores. Such results indicate that the more non-persistent mistakes one presents, i.e., the lower the capacity to maintain the context, the higher the Neuroticism indices are and lower the Extroversion indices. According to Kuzma et al., (2011) and Chapman et al. (2012), high Neuroticism indices are related to worse elderly performance in cognitive tasks, a fact that may reflect the chronic stress effect on cognitive aging. Another hypothesis to explain this result would be that lower capacity to maintain contexts would be associated with lower capacity to solve problems (Ayotte et al., 2009), a fact that would reflect lower assertiveness and would correspond to a lower Extroversion index.

The results in the current study demonstrate a positive relationship between the Neuroticism factor and depressive symptomatology, and a negative to moderate relationship between the Openness to experience factor and depression symptomatology. The analyses indicate the crucial role of the depression symptoms as the predictor more strongly associated, in regards to the others, with higher Neuroticism indices and lower Extroversion, Openness to experience, and Conscientiousness. The non-persistent mistakes in the WCST were verified to be strongly related, in comparison to the others, to higher Neuroticism scores and to lower Extroversion in the studied sample.

These results are considered an important contribution to the study, widening the understanding on the relationship among personality factors, depression symptoms, and cognitive functioning in the elderly. The results reinforce the importance of assessing cognitive functioning along with the evaluation of personality factors and depressive symptomatology in the elderly.

Among the limitations of the current study, the reduced size of the sample is highlighted as well as the elderly's high school level of educational attainment, a fact that does not reflect the reality of the Brazilian elderly population in general. The small number of men impaired the comparison between genders in relation to the studied variables. As for further studies, one suggestion would be studying the combination of different personality factors and the comparison of elderly groups with and without depression symptoms. Additionally, this study emphasizes the importance of conducting future research on this topic in order to deepen the knowledge of personalities in different age groups, and to assess whether it remains associated with cognitive performance and depressive symptoms in the elderly population. 


\section{References}

Ayotte, B. J., Potter, G. G., Williams, H. T., Steffens, D. C., \& Bosworth, H. B. (2009). The moderating role of personality factors in the relationship between depression and neuropsychological functioning among older adults. International Journal of Geriatric Psychiatry, 24(9), 1010-1019. doi: 10.1002/gps.2213

ABEP - Associação Brasileira de Empresas de Pesquisa (2012). Critério de classificação econômica Brasil. São Paulo. Associação Brasileira de Empresas de Pesquisa. Critério de Classificação Econômica Brasil. São Paulo, SP: ABEP.

Beats, B. C., Sahakian, B. J., \& Levy, R. (1996). Cognitive performance in tests sensitive to frontal lobe dysfunction in the elderly depressed. Psychological Medicine, 26(3), 591-603. doi: 10.1017/S0033291700035662

Bechara, A. (2007). Iowa Gambling Task professional manual. Lutz, FL: Psychological Assessment Resources.

Boone, K. B., Lesser, I. M., Miller, B. L., Wohl, M., Berman, N., Lee, A., Palmer, B., \& Back, C. (1995). Cognitive functioning in older depressed outpatients: Relationship of presence and severity of depression to neuropsychological test scores. Neuropsychology, 9(3), 390-398. doi: 10.1037/0894-4105.9.3.390

Booth, J., Schinka, J., Brown, L., Mortimer, J., \& Borenstein, A. (2006). Five-factor personality dimensions, mood states, and cognitive performance in older adults. Journal of Clinical and Experimental Neuropsychology, 28(5), 676-683. doi: 10.1080/13803390590954209

Brucki, S. M. D., Malheiros, S. M. F., Okamoto, I. H., \& Bertolucci, P. H. F. (1997). Dados normativos sobre o teste de fluência verbal categoria animais em nosso meio. Arquivos de Neuropsiquiatria, 55(1), 57-61. doi: 10.1590/S0004-282X1997000100009

Chapman, B. P., Duberstein, P. R., Tindle, H. A., Sink, K. M. Robbins, J., Tancredi, D. J., \& Franks, P. Gingko Evaluation of Memory Study Investigators. (2012). Personality predicts cognitive function over seven years in older persons. American Journal of Geriatric Psychiatry, 20(7), 612-621. doi: 10.1097/JGP.0b013e31822cc9cb

Chaves, M. L., \& Izquierdo, I. (1992). Differential diagnosis between dementia and depression: A study of efficiency increment. Acta Neurologica Scandinavia, 85(6), 378-382. doi: 10.1111/j.1600-0404.1992.tb06032.x

Costa Jr., P. T., \& McCrae, R. R. (2010). NEO PI-R: Inventário de personalidade NEO revisado e inventário de cinco fatores NEO revisado NEOFFI-R [versão curta]. São Paulo, SP: Vetor.

Cotta, M. F., Malloy-Diniz, L. F., Nicolato, R., de Moares, E. N., Rocha, F. L., \& de Paula, J. J. (2012). O Teste de Aprendizagem AuditivoVerbal de Rey (RAVLT) no diagnóstico diferencial do envelhecimento cognitivo normal e patológico. Contextos Clínicos, 5(1), 10-25. doi: 10.4013/ctc.2012.51.02

Figueiredo, V. L. M., \& Nascimento, E. (2007). Desempenhos nas duas tarefas do subteste dígitos do WISC-III e do WAIS-III. Psicologia: teoria e pesquisa, 23(3), 313-318. doi: 10.1590/S0102-37722007000300010

Fonseca, A. (2006). O envelhecimento: uma abordagem psicológica. ( $2^{\mathrm{a}}$ ed.). Lisboa: Universidade Católica Editora.

Fuentes, D., Moreno, C., Sassi, F., Frambati, L., Lacerda, J., \& Malloy-Diniz, L. F. (2010). Avaliação da personalidade e sua contribuição à avaliação neuropsicológica. In: L. F. Malloy-Diniz, D. Fuentes, P. Mattos, \& N. Abreu, (Orgs.), Avaliação neuropsicológica (pp.198-208). Porto Alegre: ARTMED.

Hamdan, A. C., \& Bueno, O. F. A. (2005). Relações entre controle executivo e memória episódica verbal no comprometimento cognitivo leve e na demência tipo Alzheimer. Estudos de Psicologia, 10(1), 63-71. doi: 10.1590/S1413-294X2005000100008

Irigaray, T. Q., \& Schneider, R. H. (2007). Características de personalidade e depressão em idosas da Universidade para a Terceira Idade (UNITI/UFRGS). Revista de Psiquiatria do Rio Grande do Sul, 29(2), 169-175. doi: 10.1590/S0101-81082007000200008

Knutson, B., Momenan, R., Rawlings, R. R., Fong, G. W., \& Hommer, D. (2001). Negative association of neuroticism with brain volume ratio in healthy humans. Biological psychiatry, 50(9), 685-690. doi: 10.1016/S0006-3223(01)01220-3

Kongs, S. K., Thompson, L. L., Iverson, G. L., \& Heaton, R. K. (2000). Wisconsin Card Sorting Test - 64 card version: Professional manual. Odessa: Psychological Assessment Resources.

Koorevaar, A. M., Comijs, H. C., Dhondt, A. D., van Marwijk, H. W., van der Mast, R. C., Naarding, P., Oude Voshaar, R. C., \& Stek, M. L. (2013). Big Five personality and depression diagnosis, severity and age of onset in older adults. Journal of affective disorders, 151(1), 178-185. doi: 10.1016/j.jad.2013.05.075

Krikorian, R., Bartok, J., \& Gay, N. (1994). Tower of London procedure: A standard method and developmental data. Journal of Clinical and Experimental Neuropsychology, 16(6), 840-850. doi: 10.1080/01688639408402697

Kuzma, E., Sattler, C., Toro, P., Schönknecht, P., \& Schroder, J. (2011). Premorbid personality traits and their course in mild cognitive impairment: Results from a prospective population-based study in Germany. Dementia and Geriatric Cognitive Disorders, 32(3), 171-177. doi: 10.1159/000332082

Lezak, M.D., Howieson, D.B., Bigler, E.D., \& Tranel, D. (2012). Neuropsychological assessment. $5^{\text {th }}$ ed. New York: Oxford University Press.

Löckenhoff, C. E, Terraciano, A., Ferrucci, L., \& Costa, Jr., P. T. (2012). Five-factor personality traits and age trajectories of self-rated health: The role of question framing. Journal of Personality, 80(2), 375-401. doi: 10.1111/j.1467-6494.2011.00724.x

Machado, T. H., Fichman, H. C., Santos, E. L., Carvalho, V. A., Fialho, P. P., Koeing A. M., Fernandes, C. S., Lourenço, R. A., Paradela, E. M. P., \& Carameli, P. (2009). Normative data for healthy elderly on the phonemic verbal fluency task - FAS. Dementia and Neuropsychologia, 3(1), 55-60. doi: 10.1590/S1980-57642009DN30100011

Malloy-Diniz, L. F., Lasmar, V. A., Gazinelli, L. S, Fuentes D., \& Salgado J. V. (2007) The Rey auditory-verbal learning test: Applicability for the Brazilian elderly population. Revista Brasileira Psiquiatria, 29(4): 324-329. doi: 10.1590/S1516-44462006005000053

Malloy-Diniz, L. F., Mattos, P., Moraes, P. H. P. D., Corrêa, H., Bechara, A., \& Fuentes, D. (2008). Brazilian Portuguese version of the Iowa Gambling Task: Transcultural adaptation and discriminant validity. Revista Brasileira de Psiquiatria, 30(2), 144-148. doi: 10.1590/S1516-44462008005000009

Moreira, A. G. G., Malloy-Diniz, L. F., Fuentes, D., Correa, H., \& Lage, G. M. (2010). Atividade física e desempenho em tarefas de funções executivas em idosos saudáveis: dados preliminares. Revista de Psiquiatria Clínica, 37(3), 109-112. doi: 10.1590/S0101-60832010000300003

Mota, M. M. P. E., Banhato, E. F. C., Silva, K. C. A., \& Cupertino, A. P. F. B. (2008). Triagem cognitiva: comparações entre o mini-mental e o teste de trilhas. Estudos de Psicologia, 25(3), 353-359. doi: 10.1590/S0103-166X2008000300004

Nebes, R. D., Butters M. A., Mulsant, B. H., Pollack, B. G., Zmuda, M. D., Houck, P. R., \& Reynolds, C. F.3rd. (2000). Decreased working memory and processing speed mediate cognitive impairment in geriatric depression. Psychological Medicine, 30(3), 679-691. doi: 10.1017/S0033291799001968

Nguyen, C. M., Barrash, J., Koenigs, A. L., Bechara, A., Tranel, D., \& Denburg, N. L. (2013). Decision-making deficits in normal elderly persons associated with executive personality disturbances. International Psychogeriatrics, 25(11), 1811-1819. doi: 10.1017/S1041610213001270

Paula, J. J., Costa, D. S., Moraes, E. N., Nicolato, R., \& Malloy-Diniz, L. F. (2012). Contribuições da Torre de Londres para o exame do planejamento em idosos com comprometimento cognitivo leve. Revista Neuropsicología Latinoamericana, 4(2), 16-21. 
Roberts, B. W., \& Mroczek, D. (2008). Personality trait change in adulthood. Current Directions in Psychological Science, 17(1), 31-35. doi: 10.1111/j.1467-8721.2008.00543.x

Salgado, J. V., Malloy-Diniz, L. F., Abrantes, S. S., Moreira, L., Schlottfeldt, C. G., Guimarães, W., Freitas, M. U., Oliveira, J., \& Fuentes, D. (2011). Applicability of the Rey auditory-verbal learning test to an adult sample in Brazil. Revista Brasileira de Psiquiatria, 33(3), 234-237. doi: 10.1590/ S1516-44462011005000007

Schneider, D. D. G., \& Parente, M. A. M. P. (2006). O desempenho de adultos jovens e idosos no Iowa Gambling Task (IGT): um estudo sobre a tomada de decisão. Psicologia: Reflexão e Crítica, 19(3), 442-450. doi: 10.1590/S0102-79722006000300013

Strauss, E., Sherman, E. M. S., \& Spreen, O. (2006). A Compendium of neuropsychological tests: Administration, norms and commentary. New York: Oxford University Press.

Sutin, A. R., Terracciano, A., Deiana, B., Naitza, S., Ferrucci, L., Uda, M., Schlessinger, D., \& Costa, P. T. Jr. (2010). High neuroticism and low conscientiousness are associated with interleukin-6. Psychological Medicine, 40(9), 1485-1493. doi: 10.1017/S0033291709992029

Sutin, A. R., Terracciano, A., Kitner-Triolo, M. H., Uda, M., Schlessinger, D., \& Zonderman, A. B. (2011). Personality traits prospectively predict verbal fluency in a lifespan sample. Psychology and Aging, 26(4), 994-999. doi: 10.1037/a0024276

Terracciano, A., Sutin, A. R., An, Y., O’Brien, R. J., Ferrucci, L., Zonderman, A. B., \& Resnick, S. M. (2014). Personality and risk of Alzheimer's disease: New data and meta-analysis. Alzheimer's \& Dementia, 10(2), 179-186. doi: 10.1016/j.jalz.2013.03.002

Tombaugh, T. N., Kozak, J., \& Rees, L. (1999). Normative data stratified by age and education for two measures of verbal fluency: FAS and animal naming. Archives of Clinical Neuropsychology, 14(2), 167-177. doi: 10.1016/S0887-6177(97)00095-4

Trentini, C. M., Hutz, C. S., Bandeira, D. R., Teixeira, M. A. P., Gonçalves, M. T. A., \& Thomazoni, A. R. (2009). Correlações entre a EFN - Escala Fatorial de Neuroticismo e o IFP - Inventário Fatorial de Personalidade. Avaliação Psicológica, 8(2), $209-217$.

Trentini, C. M., Argimon, I. L., Oliveira, M. S., \& Werlang, B. G. (2010). Teste Wisconsin de classificação de cartas: versão para idosos: adaptação e padronização brasileira. São Paulo, SP: Casa do Psicólogo.

Tsubota-Utsugi, M., Satoh, M., Hosaka, M., Inoue, R., Asayama, K., Hirose, T., Metoki, H., Kikuya, M., Imai, Y., \& Ohkubo, T. (2014). Personality traits as predictors of decline in higher-level functional capacity over a 7-year follow-up in older adults: The Ohasama study. The Tohoku journal of experimental medicine, 234(3), 197-207. doi: 10.1620/tjem.234.197

Wechsler, D. (2004). WAIS-III: Escala de inteligência Wechsler para adultos. São Paulo, SP: Casa do Psicólogo.

Weiss, A., Sutin, A. R., Duberstein, P. R., Friedman, B., Bagby, R. M., \& Costa, Jr., P. T. (2009). The personality domains and styles of the five-factor model are related to incident depression in Medicare recipients aged 65 to 100. The American Journal of Geriatric Psychiatry, 17(7), 591-601. doi: 10.1097/JGP.0b013e31819d859d

Wilson, R. S., Evans, D. A. Bienias, J. L., Mendes De Leon, C. F., Schneider, J. A., \& Bennett, D. A. (2003). Proneness to psychological distress is associated with risk of Alzheimer's disease. Neurology, 61(11), 1479-1485. doi: 10.1212/01.WNL.0000096167.56734.59

Wood, S., Busemeyer, J., Koling, A., Cox, C. R., \& Davis, H. (2005). Older adults as adaptive decision makers: Evidence from the Iowa Gambling Task. Psychology and Aging, 20(2), 220-225. doi: 10.1037/0882-7974.20.2.220

Yesavage, J. A., Brink, T. L., Rose, T. L., Lum, O., Huang, V., Adey, M., \& Leirer, V. O. (1983). Development and validation of a geriatric depression screening scale: A preliminary report. Journal of Psychiatric Research, 17(1), 37-39. doi: 10.1016/0022-3956(82)90033-4

\section{About the authors}

Valéria Gonzáti is a psychologist, Master in Psychology from PUCRS, collaborator of the Psychological Evaluation Commission of the Regional Council of Psychology - 7th region, Specialist in Neuropsychology by CFP, member of the Research Group Evaluation, Rehabilitation and Human-Animal Interaction (ARIHA) Program Of Post-Graduation in Psychology of PUCRS.

Irani Iracema de Lima Argimon is a psychologist, specialist in Applied Toxicology (PUCRS, 1990). He holds a Masters in Education and a PhD in Psychology. Cognitive-Behavioral Therapist certified by the Brazilian Foundation of Cognitive Therapies (FBTC, 2015). She is coordinator of the Research Group on Evaluation and Intervention in the Life Cycle of the PPGP of PUCRS since 2004. Bolsa Productividad CNPq. Full Professor of the Graduate and Post-Graduation courses in Psychology at PUCRS. Full Professor of Post-Graduation at the Geriatrics and Gerontology Institute of PUCRS.

Cristiane Silva Esteves is a psychologist, specialist in clinical care, emphasis on Psychoanalysis by UFRGS. Master in Clinical Psychology from PUCRS. PhD in Biomedical Gerontology by PUCRS.

Tatiana Quarti Irigaray is a psychologist, specialist in Clinical Psychology with emphasis in Psychological Evaluation and Neuropsychology by UFRGS. She completed an Fellowship in Neuropsychology at the Hospital de Clínicas in Porto Alegre. She holds a PhD in Biomedical Gerontology from the Pontifical Catholic University of Rio Grande do Sul (PUCRS). Has postdoctoral degree in Psychology by PUCRS. She is currently Professor of the Graduate Program in Psychology at the Humanities School of PUCRS, coordinator of the research group Evaluation, Rehabilitation and Human-Animal Interaction (ARIHA) and coordinator of the Scientific Committee of the Humanities School of PUCRS.

Camila Rosa de Oliveira is a psychologist from the Federal University of Rio Grande do Sul, a Master's degree in Psychology (emphasis on Human Cognition) from the Pontifical Catholic University of Rio Grande do Sul and a PhD in Biomedical Gerontology from the Pontifical Catholic University of Rio Grande do Sul. Post-Doctorate in Psychology from the Pontifical Catholic University of Rio Grande do Sul. She is also a research professor at the Stricto Sensu Center in Psychology at IMED, where she is research coordinator of the Psychology course and member of the Research Ethics Committee.

Carmen Moret-Tatay is a psychologist, professor of Cognitive Science and Methodology in Valencia (Spain) of the Catholic University of Valencia, San Vicente Mártir. Master in Cognitive Neuroscience at the Universitat de València and PhD in applied mathematics in cognitive science at the Universitat Politécnica de València. Director of the research group Methods of investigation in Behavioral Sciences and Technological Innovation of the Catholic University of Valencia, San Vicente Mártir. 